\title{
IMPACT OF THE SECOND STAGE OF CARDIAC REHABILITATION ON BMI IN PATIENTS AFTER CARDIAC INCIDENTS
}

\section{WPŁYW DRUGIEGO ETAPU REHABILITACJI KARDIOLOGICZNEJ NA WSKAŹNIK BMI U PACJENTÓW PO ZAWALE MIĘŚNIA SERCOWEGO}

\author{
Bartosz Mroczkowski $^{1(\mathrm{~A}, \mathrm{~B}, \mathrm{C}, \mathrm{D}, \mathrm{E}, \mathrm{F})}$, Monika Kurzaj $^{1(\mathrm{C}, \mathrm{D}, \mathrm{E})}$, \\ Karolina Jacyno $^{1(\mathrm{~A}, \mathrm{~B}, \mathrm{~F})}$, Krystyna Rożek-Piechura ${ }^{1(\mathrm{~A}, \mathrm{C}, \mathrm{D}, \mathrm{E}, \mathrm{F})}$
}

${ }^{1}$ University School of Physical Education, Wrocław, Poland

Authors' contribution Wkład autorów: A. Study design/planning zaplanowanie badań B. Data collection/entry zebranie danych

C. Data analysis/statistics dane - analiza i statystyki D. Data interpretation interpretacja danych E. Preparation of manuscript przygotowanie artykułu F. Literature analysis/search wyszukiwanie i analiza literatury G. Funds collection zebranie funduszy
Tables: 5

Figures: 0

References: 23

Submitted: 2018 Nov 14

Accepted: 2019 Jan 10

\section{Summary}

Background. Cardiovascular disease is currently one of the leading causes of death in the world, and a major contributing factor is the increasing incidence of excessive body mass. On the other hand, reduction of body mass in patients who have experienced a myocardial infarction significantly reduces the risk of a second episode of cardiovascular disease. This in turn increases lifespan, improves quality of life, and reduces the number of premature deaths. Material and methods. The study included 41 people $(14$ women with an average age of 62.5 years and 27 men with an average age of 61.2 years) who experienced a cardiac incident between January 2015 and February 2016 and who were qualified for the second stage of cardiac rehabilitation conducted in accordance with applicable standards.

Results. BMI did not correlate with the results of exercise tests. The training improved the fitness and endurance of the subjects and allowed reduction of body mass.

Conclusions. After 8 weeks of the second stage of cardiac rehabilitation, there were significant changes in the BMI in patients undergoing the study. Exercise tolerance and physical capacity in all the groups was improved.

Keywords: cardiac rehabilitation, Body Mass Index, excess body weight, obesity

\section{Streszczenie}

Wprowadzenie. Choroba sercowo-naczyniowa jest obecnie jedną z głównych przyczyn zgonów na świecie. Narastającym problemem jest zbyt duża masa ciała, która jest jednym z głównych czynników powodujacych stany sercowo-naczyniowe. U pacjentów po zawale mięśnia sercowego zmniejszenie BMI znacznie redukuje ryzyko drugiego zaostrzenia choroby sercowo-naczyniowej, co zwiększa długość i komfort życia oraz zmniejsza liczbę zgonów.

Materiał i metody. Badaniem objęto 41 osób - 14 kobiet (62,5 roku) i 27 mężczyzn (61,2 lat), u których doszło do incydentu kardiologicznego między styczniem 2015 r. a lutym 2016 r., i które zakwalifikowano do drugiego etapu rehabilitacji kardiologicznej prowadzonego zgodnie z obowiązującymi standardami.

Wyniki.BMI nie koreluje istotnie z wynikami badań wysiłkowych. Ukończony trening poprawił kondycję i wytrzymałość uczestników oraz pozwolił zmniejszyć masę ciała.

Wnioski. Po 8 tygodniach drugiego etapu rehabilitacji kardiologicznej wystąpiły istotne zmiany w BMI u pacjentów poddanych badaniu. Poprawiono tolerancję wysiłkowąi wydolność fizyczną we wszystkich badanych grupach.

Słowa kluczowe: rehabilitacja kardiologiczna, BMI, nadwaga, otyłość

\section{Introduction}

The main diseases of civilization that currently cause the largest number of deaths are cardiovascular conditions, and in particular, coronary artery disease [1]. According to statistics from the World Health Organization, about 17 million people die every year from cardiovascular illnesses. The highest death rate is due to ischemic heart disease [2].

The main predisposing factor behind the emergence and development of heart disease is the lack of a healthy lifestyle, which leads to excess weight and its complications [3]. On the basis of epidemiological data, the World Health Organization states that obesity is considered an epidemic of our time [4] and has been classified as a chronic non-infectious disease. According to the report by the World Health Organization about $18 \%$ of adults in developed countries suffer from obesity [5]. Moreover, the results of the NATPOL 2011 study show an

Mroczkowski B, Kurzaj M, Jacyno K, Rożek-Piechura K. Impact of the second stage of cardiac rehabilitation on BMI in patients after cardiac incidents. Health Prob Civil. 2019; 13(3): 201-208. https://doi.org/10.5114/hpc.2019.81341

\footnotetext{
Address for correspondence / Adres korespondencyjny: Bartosz Mroczkowski, University School of Physical Education, Ignacego Jana Paderewskiego 35, 51-612 Wrocław, Poland, e-mail: bartosz.mroczkowski90@gmail.com, phone: +48 694411 575. ORCID: Krystyna Rożek-Piechura https://orcid.org/0000-0001-5589-4978 Copyright: (C) Pope John Paul II State School of Higher Education in Biała Podlaska, Bartosz Mroczkowski, Monika Kurzaj, Karolina Jacyno, Krystyna Rożek-Piechura. This is an Open Access journal, all articles are distributed under the terms of the Creative Commons Attribution-NonCommercial-ShareAlike 4.0 International (CC BY-NC-SA 4.0) License (http://creativecommons.org/licenses/by-nc-sa/4.0/), allowing third parties to copy and redistribute the material in any medium or format and to remix, transform, and build upon the material, provided the original work is properly cited and states its license.
} 
unfavorable growing trend regarding the body mass of subjects in Poland. On the basis of the study results, it is forecasted that by 2035 the number of people suffering from obesity will increase from $22 \%$ to $33 \%$ (from 6.5 million people to over 9 million people) [6].

The aim of comprehensive cardiac rehabilitation is to improve the patients' quality of life, consolidate the effects of their cardiac treatment and improve their overall fitness and efficiency. The additional detailed objectives of cardiac rehabilitation are selected individually for each patient, depending on their needs and physical, economic and social capabilities. They can be related to the regulation and stabilization of blood pressure, weight loss, improvement of blood biochemical components and many other individually selected goals. The increase in the overall fitness and efficiency of the patient's body enables him to return to work and allows him to become independent with everyday activities. In addition, rehabilitation has a positive effect on limiting the progression of disease, counteracting complications and improving the quality and comfort of life $[7,8]$.

The aim of this article is to assess the impact of the second stage of cardiac rehabilitation on changes in BMI and exercise tolerance of patients after cardiac events.

\section{Material and methods}

\section{The study group}

The subjects were in the care of a cardiologist who, in the course of qualifying them for cardiac rehabilitation, ruled out contraindications to participation in this study. Additionally, each of the subjects gave written consent for participation in research, sharing results and processing of personal data collected for scientific purposes. The study was conducted from October 2015 to April 2016.

The study included 41 people-14 women (62.5 years \pm 8.32 ) and 27 men (61.2 years \pm 10.18$)-$ who experienced a cardiac incident between January 2015 and February 2016 and were qualified for the second stage of cardiac rehabilitation. This rehabilitation was conducted by the Center for Prevention and Rehabilitation (CREATOR) located at Lotnicza 37 Street, the city of Wrocław.

All 41 participants had an intervention for coronary artery disease: 31 had stent placement and 10 had coronary artery bypass surgery. Occurring co-morbidities and medications, in the assessment of the qualifying cardiologist, did not have a significant impact on the results of the study. Patients did not use a specific diet.

\section{Criteria for inclusion}

- Exacerbation of cardiac disease between January 2015 and February 2016 requiring hospitalization and cardiac intervention

- Active participation in cardiac rehabilitation

- Expressing written consent for participation in the study

\section{Exclusion criteria}

- Nicotinism

- Alcoholism

- Advanced diseases of the musculoskeletal system or amputations

- Cancer

\section{Six-Minute Walk Test}

The six-minute walk test is the simplest of many methods for objectively assessing the patient's exercise tolerance, efficiency and functionality. The tests were conducted according to general recommendations and standards of the American Association of Thoracic Diseases. The results, which were obtained using Coonors' formulas, enabled the calculation of the average speed of the walk expressed in kilometers per hour and the energy expenditure expressed in METs.

The average walk speed in the six-minute corridor test:

$$
\mathrm{V}_{\text {average }}=(\text { distance covered in meters } * 10) / 1000[\mathrm{~km} / \mathrm{h}]
$$


Energy expenditure of a six-minute corridor test:

$$
\left.\mathrm{W}_{\mathrm{E}}=\text { (average speed of walking }[\mathrm{km} / \mathrm{h}] * 1.667+3.5\right) / 3.5[\mathrm{MET}]
$$

The six-minute walk test should be performed before and after the rehabilitation stage in order to determine the effectiveness of training and exercise, and also to document progress and changes in exercise tolerance [9, $10]$.

\section{Exercise test according to the RAMP protocol}

The electrocardiogram exercise test that was performed according to the Ramp protocol took place in the Center for Prevention and Rehabilitation (CREATOR) and was conducted by a physiotherapist who used a stationary cycle ergometer (CRG200 v. 312) and ASPEL Cardio TEST software. Before the beginning of the test, blood pressure and heart rate were measured. From the second stage of the test, power was increased by 25 W every 10 seconds. Exercise heart rate was constantly monitored by an electrocardiogram. Blood pressure was measured at the end of the warm-up, immediately after the end of the trial and then after 3 minutes, and also after a recovery period, the duration of which was individual for each patient.

\section{Exercise test according to the modified Bruce protocol}

The electrocardiographic exercise test that was performed according to the modified Bruce protocol also took place in the Center for Prevention and Rehabilitation (CREATOR) and was conducted by a cardiologist who used a treadmill with an adjustable incline.

Exercise heart rate was constantly monitored by an electrocardiogram. Blood pressure was measured in the third minute of each stage, after the end of the trial and after a recovery period, which was individual for each patient.

\section{The course of cardiac rehabilitation conducted in the Center for Prevention and Rehabilitation (CREATOR)}

Patients with a referral to cardiac rehabilitation performed a series of 21 treatment sessions; these were performed three times a week. On the basis of the performed exercise tests, the patients were assigned to appropriate groups and their individual cycle ergometer endurance training was programmed. The training was conducted three times a week for 45 minutes. The rehabilitation cycle ergometer CRG200 v.312 and Aspel AsTER software were used during the training. It was a modified interval training adapted to the individual needs of the patient. The effort phase was equal to the rest phase. Most often during the training, there were 5 phases of effort with increasing difficulty level to the third phase and then decreasing to the initial state. Depending on the patient's mood on a given day of treatment, the software enables individual changes in the training that was previously programmed on the basis of electrocardiographic strength tests $[8,11]$.

General-fitness exercises was conducted every day for 30 minutes in two groups divided according to ability level. Based on the exercise test that was carried out according to the modified Bruce protocol, the patients were assigned to the appropriate rehabilitation group. In the case of the A model of cardiac rehabilitation, the gymnastics was conducted dynamically in a standing position with the use of tools and instruments located in the gymnasium. The patients performed endurance, strengthening, stretching, breathing and relaxation exercises. In patients qualified for model B cardiac rehabilitation, the exercises were conducted in a sitting position on an unstable floor. Similar to the A model, endurance, strengthening, stretching, breathing and relaxation exercises were performed. The unstable floor was intended to additionally stimulate deep torso muscles and to strengthen the postural control of patients [11]. During the cardiac rehabilitation program, patients were provided with third-degree prophylaxis in the field of cardiac disease, and each patient also had at least one visit with a psychologist.

\section{Statistical analysis}

The test results were collected and compiled in an Excel 2007 spreadsheet, and then subjected to statistical analysis by STATISTICA version 10 PL (StatSoft, USA). To test the normality of the examined parameters' distribution, the Shapiro-Wilk test was used on all the study groups. The basic descriptive statistics for measurable features were calculated: arithmetic mean, standard deviation and minimum and maximum values 
were determined. In order to determine the significance of differences between the examined parameters in the studied groups, the analysis of variance for repeated measurements and Tukey's test were used in the case of statistically significant results of variance. Additionally, Pearson's correlation coefficient was calculated for selected parameters. In the applied statistical tests, the values of coefficients and tests at the level of $p<0.05$ were assumed to be statistically significant. The relevant values are marked in the tables.

\section{Results}

Selected results that are statistically significant are presented in the tables below. Table 1 presents the basic characteristics of the group of respondents, including the division into sex. Tables 2 and 3 present basic descriptive statistics. For significant variance analysis results, the post-hoc test was conducted.

The Tukey test results are presented in Table 4. In addition, the Pearson correlation coefficient was calculated for selected parameters. The results are presented in Table 5.

Table 1. Characteristics of the subjects based on sex

\begin{tabular}{|c|c|c|c|c|}
\hline Data & \multicolumn{2}{|c|}{ Women } & \multicolumn{2}{c|}{ Men } \\
\hline Subjects (number \%) & \multicolumn{2}{|c|}{$14(34.15 \%)$} & \multicolumn{2}{c|}{$27(65.85 \%)$} \\
\hline Proper body mass & Before & After & Before & After \\
\hline Excess weight (BMI $>\mathbf{2 5} \mathbf{~ k g} / \mathbf{m}^{\mathbf{2}}$ ) & $7(14 \%)$ & $2(14 \%)$ & $3(11 \%)$ & $4(15 \%)$ \\
\hline Obesity (BMI $>\mathbf{3 0} \mathbf{~ k g} / \mathbf{m}^{2}$ ) & $5(36 \%)$ & $6(42 \%)$ & $9(33 \%)$ & $9(33 \%)$ \\
\hline
\end{tabular}

Table 2. Descriptive statistics for selected parameters - men

\begin{tabular}{|c|c|c|c|c|c|c|}
\hline Variables & $\begin{array}{c}\text { Number of } \\
\text { subjects }\end{array}$ & Average & SD & Minimum & Maximum & Median \\
\hline AGE & 27 & 61.15 & 10.18 & 42.00 & 72.00 & 62.00 \\
\hline HEIGHT & 27 & 172.76 & 6.15 & 162.00 & 186.00 & 170.50 \\
\hline MASS 1 & 27 & 91.57 & 16.34 & 66.40 & 127.00 & 92.00 \\
\hline MASS 2 & 27 & 90.25 & 15.94 & 66.30 & 124.50 & 89.60 \\
\hline BMI 1 & 27 & 30.64 & 5.00 & 23.10 & 41.50 & 30.80 \\
\hline BMI 2 & 27 & 30.20 & 4.85 & 23.10 & 40.60 & 30.30 \\
\hline 6MWT 1 & 27 & 513.43 & 87.36 & 325.00 & 675.00 & 500.00 \\
\hline 6MWT 1 V & 27 & 5.13 & 0.80 & - & - & - \\
\hline 6MWT 1 MET & 27 & 3.45 & 0.38 & - & - & - \\
\hline 6MWT 2 & 27 & 556.94 & 75.51 & 375.00 & 725.00 & 562.50 \\
\hline 6MWT 2 V & 27 & 5.57 & 0.77 & - & - & - \\
\hline 6MWT 2 MET & 27 & 3.65 & 0.38 & - & - & - \\
\hline RW 1 & 27 & 200.19 & 50.03 & 110.00 & 290.00 & 190.00 \\
\hline RW 2 & 27 & 230.45 & 44.41 & 145.00 & 320.00 & 223.00 \\
\hline BMET 1 & 27 & 8.99 & 3.51 & 2.30 & 17.20 & 10.10 \\
\hline BMET 2 & 27 & 9.92 & 4.03 & 2.30 & 17.20 & 10.10 \\
\hline
\end{tabular}

HEIGHT - body height of the subjects, MASS 1 - body weight before rehabilitation, MASS 2 - body weight after rehabilitation, BMI 1 - Body Mass Index before rehabilitation, BMI 2 - Body Mass Index after rehabilitation, 6MWT 1 - distance in meters covered in 6MWT before rehabilitation, 6MWT 2 - distance in meters covered in 6MWT after rehabilitation, 6MWT1 V average speed of walking $[\mathrm{km} / \mathrm{h}]$ in $6 \mathrm{MWT}$ before rehabilitation, 6MWT $\mathbf{2}$ V-average speed of walking $[\mathrm{km} / \mathrm{h}]$ in $6 \mathrm{MWT}$ after rehabilitation, 6MWT 1 MET - average energy expenditure [MET] in 6MWT before rehabilitation, 6MTK 2 MET - average energy expenditure [MET] in 6MWT after rehabilitation, RW 1 - RAMP protocol result (W) before rehabilitation, RW 2 RAMP protocol result (W) after rehabilitation, BMET 1 - the Modified Bruce Protocol result (MET) before rehabilitation, BMET 2 - the Modified Bruce Protocol result (MET) after rehabilitation 
Table 3. Descriptive statistics for selected parameters - women

\begin{tabular}{|c|c|c|c|c|c|c|}
\hline Variables & $\begin{array}{c}\text { Number of } \\
\text { subjects }\end{array}$ & Average & SD & Minimum & Maximum & Median \\
\hline AGE & 14 & 62.5 & 8.32 & 43.00 & 79.00 & 63.00 \\
\hline HEIGHT & 14 & 160.86 & 5.07 & 150.50 & 170.00 & 160.75 \\
\hline MASS 1 & 14 & 78.26 & 12.42 & 62.60 & 105.50 & 75.10 \\
\hline MASS 2 & 14 & 77.59 & 12.17 & 61.90 & 103.00 & 75.75 \\
\hline BMI 1 & 14 & 30.40 & 5.70 & 24.20 & 46.60 & 29.05 \\
\hline BMI 2 & 14 & 30.10 & 5.56 & 23.90 & 45.50 & 28.65 \\
\hline 6MWT 1 & 14 & 443.75 & 80.67 & 250.00 & 550.00 & 437.50 \\
\hline 6MWT 1 V & 14 & 4.44 & 0.81 & - & - & - \\
\hline 6MWT 1 MET & 14 & 3.11 & 0.38 & - & - & - \\
\hline 6MWT 2 & 14 & 477.68 & 96.35 & 275.00 & 625.00 & 481.25 \\
\hline 6MWT 2 V & 14 & 4.78 & 0.96 & - & - & - \\
\hline 6MWT 2 MET & 14 & 3.27 & 0.46 & - & - & - \\
\hline RW 1 & 14 & 132.79 & 27.66 & 83.00 & 178.00 & 139.00 \\
\hline RW 2 & 14 & 152.07 & 24.46 & 98.00 & 190.00 & 152.50 \\
\hline BMET 1 & 14 & 5.15 & 3.18 & 2.30 & 10.10 & 4.30 \\
\hline BMET 2 & 14 & 6.46 & 3.42 & 2.30 & 13.40 & 7.00 \\
\hline
\end{tabular}

HEIGHT - body height of the subjects, MASS 1 - body weight before rehabilitation, MASS 2 - body weight after rehabilitation, BMI 1 - Body Mass Index before rehabilitation, BMI 2 - Body Mass Index after rehabilitation, 6MWT 1 - distance in meters covered in 6MWT before rehabilitation, 6MWT 2 - distance in meters covered in 6MWT after rehabilitation, 6MWT1 V average speed of walking $[\mathrm{km} / \mathrm{h}]$ in 6MWT before rehabilitation, 6MWT $2 \mathrm{~V}$-average speed of walking [km/h] in 6MWT after rehabilitation, 6MWT 1 MET - average energy expenditure [MET] in 6MWT before rehabilitation, 6MTK 2 MET - average energy expenditure [MET] in 6MWT after rehabilitation, RW 1 - RAMP protocol result (W) before rehabilitation, RW 2 RAMP protocol result (W) after rehabilitation, BMET 1 - the Modified Bruce Protocol result (MET) before rehabilitation, BMET 2 - the Modified Bruce Protocol result (MET) after rehabilitation

Table 4. Impact assessment of rehabilitation on the values of selected parameters (Tukey test)

\begin{tabular}{|c|c|c|c|c|c|c|c|c|c|c|}
\hline & $\mathbf{1}$ & $\mathbf{2}$ & $\mathbf{3}$ & $\mathbf{4}$ & $\mathbf{1 - 2}$ & $\mathbf{1 - 3}$ & $\mathbf{1 - 4}$ & $\mathbf{2}-\mathbf{3}$ & $\mathbf{2}-\mathbf{4}$ & $\mathbf{3}-\mathbf{4}$ \\
\hline BMI & 30.393 & 30.641 & 30.100 & 30.200 & $\mathbf{0 . 0 0 0 1 6 5}$ & 0.999328 & 0.992561 & 0.999690 & 0.999957 & $\mathbf{0 . 0 1 4 5 7 0}$ \\
\hline 6MWT & 443.75 & 513.43 & 477.68 & 556.94 & $\mathbf{0 . 0 0 1 0 5 9}$ & 0.140344 & 0.676558 & $\mathbf{0 . 0 0 4 6 6 8}$ & 0.073910 & 0.107517 \\
\hline RW & 132.79 & 200.19 & 152.07 & 230.44 & $\mathbf{0 . 0 0 0 1 8 0}$ & $\mathbf{0 . 0 0 0 5 8 4}$ & $\mathbf{0 . 0 1 7 6 9 6}$ & $\mathbf{0 . 0 0 0 1 6}$ & $\mathbf{0 . 0 0 0 2 0 0}$ & 0.081115 \\
\hline BMET & 4.7615 & 8.9926 & 6.4615 & 9.9222 & 0.323740 & $\mathbf{0 . 0 2 1 5 2 9}$ & 0.289803 & $\mathbf{0 . 0 0 3 4 5 9}$ & 0.080951 & 0.143705 \\
\hline
\end{tabular}

$\mathbf{W}_{1}$ - women before rehabilitation, $\mathbf{W}_{2}$ - women after rehabilitation, $\mathbf{M}_{1}$ - men before rehabilitation, $\mathbf{M}_{2}-$ men after rehabilitation, BMI - Body Mass Index, 6MWT - 6 Minutes Walk Test, RW - RAMP protocol result (W), BMET - the Modified Bruce Protocol result (MET) 
Table 5. Pearson correlations for selected variables

\begin{tabular}{|c|c|c|c|c|c|c|c|c|c|c|}
\hline \multirow{2}{*}{ Variable } & \multicolumn{10}{|c|}{ Pearson correlations $p<, 05000$} \\
\hline & MASS 1 & MASS 2 & BMI 1 & BMI 2 & 6MWT 1 & 6MWT 2 & RW 1 & RW 2 & BMET 1 & BMET 2 \\
\hline SEX & -0.376999 & -0.369475 & -0.010658 & 0.001433 & -0.340208 & -0.375447 & -0.604579 & -0.700520 & & -0.396745 \\
\hline AGE & -0.193187 & -0.184491 & -0.127293 & -0.116967 & -0.365681 & -0.563051 & -0.242294 & -0.318895 & -0.490853 & -0.462448 \\
\hline HEIGHT & 0.455756 & 0.458308 & -0.104651 & -0.10 & 0.244154 & 83 & 0.607275 & 0.631999 & 0.379055 & 116 \\
\hline & & & & & & & & & & \\
\hline & & & & & & & & & & \\
\hline BMI 1 & 0.832476 & 0.829428 & 1.000000 & 0.99 & & & & & & \\
\hline BMI 2 & 411 & 0.82 & 0.998 & 1.00 & -0. & 713 & 01 & & & \\
\hline 6MWT 1 & -0.1 & -0.1 & -0.306209 & -0.33 & & 922 & 398 & 111 & 0. & 036 \\
\hline 6MWT 2 & & & & & & & & & & \\
\hline RW 1 & 0.448569 & & & & & & & 0.852217 & 0.58 & \\
\hline RW 2 & 0.354229 & 0.351238 & 0.019 & & & & 217 & 1.000000 & & 3922 \\
\hline & 0.094145 & 0.081441 & -0.141396 & -0.158016 & 0.602303 & \begin{tabular}{|l|}
0.743388 \\
\end{tabular} & 0.584440 & 0.684330 & 1.000000 & 0.759999 \\
\hline BMET 2 & 0.109766 & 0.095719 & -0.178410 & -0.196258 & 0.528036 & 0.638447 & 0.481459 & 0.663922 & 0.759999 & 1.000000 \\
\hline
\end{tabular}

HEIGHT - body height of the subjects, MASS 1 - body weight before rehabilitation, MASS 2 - body weight after rehabilitation, BMI 1 - Body Mass Index before rehabilitation, BMI 2 - Body Mass Index after rehabilitation, 6MWT 1 - distance in meters covered in 6MWT before rehabilitation, 6MWT 2 - distance in meters covered in 6MWT after rehabilitation, RW 1 - RAMP protocol result (W) before rehabilitation, RW 2 - RAMP protocol result (W) after rehabilitation, BMET 1 - the Modified Bruce Protocol result (MET) before rehabilitation, BMET 2 - the Modified Bruce Protocol result (MET) after rehabilitation

\section{Discussion}

The results of our study show that the use of standard cardiac rehabilitation has a significant impact on improvement of the examined parameters.

The process of treating cardiac patients has recently been refined by the development of better technologies, techniques and methods. Szmit et al. in their studies confirm that, due to the application of new specialized techniques and technologies, contemporary comprehensive cardiac care positively affects the human body. It reduces the number of premature deaths, improves quality of life and reduces recuperation time [12]. These studies also confirm that, despite the use of all available therapies, it is not possible to completely heal ischemic heart disease, but only to slow its progression. Available literature turns particular attention to the fact that regular physical effort is a very important element of the therapy for patients who have had cardiac incidents or who have other cardiovascular diseases $[13,14,15,16]$. According to the authors, the treatment of ischemic heart disease may involve pharmacological therapy or surgical treatment; however, it is always necessary to perform comprehensive cardiac rehabilitation. Cardiac rehabilitation reduces the mortality caused by cardiovascular diseases by $30 \%$ per annum. It aims to improve exercise tolerance, increase functional fitness and return the patient to their everyday life from before the diagnosis. Benefits of comprehensive cardiac rehabilitation have been confirmed and documented by many studies and cardiac rehabilitation is recommended as part of a complete treatment plan for cardiovascular diseases by the American Heart Association and the American College of Cardiology.

Storch-Uczciwek et al. in their meta-analysis also present many studies that confirm the positive effect of adequate and regular physical activity on the treatment and prevention of heart disease [17].

Skrypnik et al. showed that appropriate physical training improves exercise tolerance, enhancing the quality of mental and physical life and, as a consequence, reducing the number of exacerbations and deaths [18]. The study indicates that the best effects of physical training have been induced in patients with chronic heart failure who were assessed as NYHA class II and III. The authors emphasize that the positive effects of using physical training are possible only with an appropriate and systematic form, such as general exercises and endurance training on a cycle ergometer [18].

Our study indicates a statistically significant difference in endurance parameters as measured in exercise tests, and confirmed the effectiveness of cardiac rehabilitation in the form of regular and monitored physical exercise.

According to studies by many authors, the physical capacity of the body and exercise tolerance are important prognostic factors in patients with cardiovascular conditions. In his research, Paduch demonstrated that coronary artery bypass grafting surgery and the second stage of comprehensive cardiac rehabilitation, conducted in an outpatient mode according to the current standards and guidelines of the Polish Cardiac Society, brings a lot 
of benefit to the patient. It was particularly important to increase exercise tolerance and the duration of the exercise test $[19,20]$.

In the study by Podsiadły et al, a significant increase in the duration of exercise tests was demonstrated both in the group of patients that had coronary artery bypass grafting and in the group that had stent implantation [21].

The results of our own study confirm the positive correlation between improving exercise tolerance and increasing the duration of exercise tests. The exercise time was extended both during the RAMP test and the modified Bruce protocol. The majority of the subjects in our study were overweight or obese. Already in 1997 the relationship between obesity and the risk developing of cardiovascular disease had been shown. It was also shown that the progressive remodeling of the heart muscle associated with excessive body weight significantly increases the risk of arrhythmias and sudden cardiac death [22].

Kotseva et al. in their studies showed that an increasing part of the studied population has a problem with abnormal body mass. Estimates by the World Health Organization indicate that globally, the problems of overweight and obesity may affect up to $30 \%$ of women and $24 \%$ of men. Over the last decade, there has been a nearly $15 \%$ increase in the number of obese women with diagnosed ischemic heart disease. Analyzing the results of numerous Polish and other scientists who deal with the problem of abnormal body weight shows that overweight is more frequently observed in men, while obesity is noted more frequently in women $[6,23]$.

The majority of patients that took part in our study, both women and men, were characterized by an abnormal, elevated body mass. This confirms the presented thesis that there is a relationship between cardiovascular diseases and abnormal body mass - excessive body mass or obesity. However, it has not been confirmed that men more often struggle with overweight, and women with obesity. The results of our study indicate the opposite situation. Most of the examined men suffered from obesity, while the BMI in half of the surveyed women was in the "overweight" category.

The applied model of cardiac rehabilitation results from the recommendations described by Piotrowicz et al. In 2004, individual models of cardiac rehabilitation were developed, which were adopted as a standard. Their effectiveness has been confirmed by various tests carried out on many levels. This work also demonstrates the effectiveness of the described and adopted standard [11].

The results of our study, as well as a number of analyzed research outcomes of many authors, show the effectiveness of complex cardiac rehabilitation as the main element of treatment and prophylaxis in patients who have experienced cardiac incidents or who are at risk for cardiovascular disease. As has already been mentioned, the education of patients and people at risk is just as important as individual training and exercises. Obesity and excess body mass influence the development of cardiovascular disease as well as other serious conditions. Analysis of the results of our study and others indicate similar tendencies, confirming the improvement of exercise tolerance and reduction of energy expenditure after the completion of the second stage of cardiac rehabilitation. A reduction in the BMI was also noted in the subjects.

\section{Conclusions}

Analyzing the results of this study provides answers to the research questions:

1. The second stage of comprehensive cardiac rehabilitation, conducted according to applicable principles and guidelines, significantly reduced the value of BMI regardless of the sex of the examined patients.

2. On the basis of statistical analysis using Pearson's correlation, no significant connection was found between increased BMI and the effectiveness of the second stage of cardiac rehabilitation measured by the Watt and MET load during the exercise test.

3. The value of BMI of the examined patients calculated after completion of cardiac rehabilitation indicates a statistically significant connection with exercise tolerance.

4. The analysis of results after completion of the second stage of cardiac rehabilitation showed a decrease in the body mass of the subjects and a reduction in the BMI. In addition, the length of the distance covered in the six-minute corridor test and the value of electrocardiographic stress test results, conducted according to the RAMP protocol and the modified Bruce protocol, were increased. The above-mentioned parameters have changed statistically significantly. 


\section{References:}

1. Bortkiewicz A. [Diseases of the circulatory system in the aspect of work. Guide for doctors]. Łódź: Instytut Medycyny Pracy Im. Prof. J. Nofera; 2011 (in Polish).

2. World Health Organization. The European health report 2012. Charting the way to well-being. Geneva: World Health Organization; 2012.

3. Przybylska D, Kurowska M, Przybylski P. [Obesity and overweight in the adolescent population]. Hygeia Public Health. 2012; 47(1): 28-35 (in Polish).

4. Kłosiewicz-Latoszek L. [Obesity as a social, medical and therapeutic problem]. Problemy Higieny i Epidemiologii. 2010; 91(3): 339-343 (in Polish).

5. Rymarczyk Z, Bienias P, Domienik-Karłowicz J, Pruszczyk P, Ciurzyński M. [Impact of obesity on electrocardiographic abnormalities, cardiac arrhythmias and autonomic nervous system dysfunction]. Choroby Serca i Naczyń. 2015; 12(2): 96-107 (in Polish).

6. Stanisławska J, Talarska D, Kudlińska A. [Comparison of risk factors for coronary heart disease in patients after myocardial infarction with patients without clinical signs of the disease]. Hygeia Public Health. 2014; 49(1): 127-133 (in Polish).

7. Fudalej D, Nowak Z, Plewa M. [The effect of coronary artery bypass grafting and early and late rehabilitation on the efficiency of patients after myocardial infarction in the first year after surgery]. Fizjoterapia Polska. 2002; 2(4): 285-289 (in Polish).

8. Krakowska A, Sikorska J, Michalak Ł, Ludwikowska L, Kopacz K, Kubica A, et al. [Strategy for rehabilitation after cardiac surgery]. Folia Cardiologica. 2010; 5(3): 135-140 (in Polish).

9. American Thoracic Society. ATS statement: guidelines for the six-minute walk test. Am J Respir Crit Care Med. 2002; 166: 111-117. https://doi.org/10.1164/ajrccm.166.1.at1102

10. Łazorczyk M, Ponikowski P. [Application of a 6-minute corridor test in patients with heart failure] [Doctoral dissertation in physical education]. Wrocław: AWF Wrocław; 2005 (in Polish).

11. Piotrowicz R, Dylewicz P, Jegier A. [Comprehensive cardiac rehabilitation]. Folia Cardiologica. 2004; 11(supl. A): A1-A48 (in Polish).

12. Szmit S, Filipiak K. [Is physical activity important for a patient with heart disease?]. Przewodnik Lekarza. 2007; 7: 32-38 (in Polish).

13. Piotrowicz E, Baranowski R, Bilińska M, Stepnowska M, Piotrowska M, Wójcik A, et al. A new model of homebased telemonitored cardiac rehabilitation in patients with heart failure: effectiveness, quality of life, and adherence. European Jouranl of Heart Failure. 2010; 12: 164-171. https://doi.org/10.1093/eurjhf/hfp181

14. Makowiec-Dobrowska T. [Effect of physical activity at work and everyday life on the cardiovascular system]. Forum Medycyny Rodzinnej. 2012; 6(3): 130-138 (in Polish).

15. Dylewicz P, Borowicz-Bieńkowska S. [Is cardiac rehabilitation a necessity in the era of modern interventional cardiology and cardiac surgery?]. Kardiochirurgia i Torakochirurgia Polska. 2006; 3(1): $92-95$ (in Polish).

16. Rożek-Piechura K. [Expert's comment]. Rehabilitacja w Praktyce. 2015; 1: 32-33 (in Polish).

17. Storch-Uczciwek A, Bochenek A. [Influence of the cardiac rehabilitation on regular physical activity after coronary artery bypass grafting]. Fizjoterapia. 2010; 18(1): 3-8 (in Polish).

18. Skrypnik D, Cymeys M, Pupek-Musialik D. The positive effects of physical training on life quality in a 92-yearold female patient with exacerbation of chronic heart failure. Polski Przegląd Kardiologiczny. 2013; 15(1): 80-82.

19. Paduch P. [Evaluation of physical activity after coronary artery bypass graft behing assistance of Minnesota Leisure-Time Physical Activity Questionnaire]. Postępy Rehabilitacji. 2013; 27(1): 39-47 (in Polish).

20. Paduch P. [The influence of outpatient cardiac rehabilitation on physical efficiency of patients subjected to myocardial infarction]. Postępy Rehabilitacji. 2013; 27(3): 21-26 (in Polish).

21. Podsiadły K, Kowacz K, Niewiadomski P, Nowak Z, Koncewicz M. [Assessment of the efficiency of patients undergoing minimally invasive cardiac treatment: the effect of the treatment method on the effectiveness of the rehabilitation program]. Rehabilitacja w Praktyce. 2012; 4: 84-87 (in Polish).

22. World Health Organization. Obesity: preventing and managing the global epidemic. Geneva: World Health Organization; 2000. p. 46-50, 58-60.

23. Biela U, Pająk A, Kaczmarczyk-Chałas K, Głuszek J, Tendera M, Waśkiewicz A, et al. [Prevalence of overweight and obesity in women and men aged 20-74. The WOBASZ program results]. Kardiologia Polska. 2005; 63(4): 1-4 (in Polish). 